\title{
Integrated Hand Cleaner and Dryer Product Design using QFD as a Solution for New Normal Era
}

\author{
Putri Amalia, Setyawan Pratomo, Diyas Yahya, Ari Adrianto
}

\begin{abstract}
At this time the coronavirus pandemic has resulted in new adaptations in daily life through new normal rules that have many rules against public activities such as using masks, keeping distance, and maintaining cleanliness by washing hands using water or hand sanitizer after interacting with objects or people in public areas. This resulted in increased use and demand for hand sanitizers and public facilities for handwashing. This study aims to obtain the design of cleaning tools and hand dryers that suit the wishes of the community. The method used in this application of Quality Function Development (QFD) by using matrix House of Quality (HOQ) to obtain the criteria of cleaning tools and hand dryers according to the wishes of the community. The results of this study obtained the design of automatic and integrated cleaning tools and hand dryers in one tool that uses a hand sanitizer made of natural antiseptic so that it does not require water and soap and with a price range of Rp.700.000.
\end{abstract}

Keywords: Automatic, HOQ, Hand cleaner, Hand Drayer Integrated, QFD.

\section{INTRODUCTION}

$\mathrm{N}$ owadays pandemic has been changing our lives.

Since it weakens our economic aspects, mostly because of social distancing and work from home things, this year's pandemic is a worst crisis in the past 50 years [1]. For a severe respiratory virus, Coronavirus 2 that firstly found in Wuhan has killed many people in the world [2]. The pandemic that started to spread on January has infected many people in many countries, one of them is Indonesia. On September 16, the number of cases of infected people in Indonesia reached 225,030 people with 8,965 death cases. This matter is getting serious and need some adaptation to do daily activities. Some governments and also WHO already published new normal regulations. As in [3], in have published for the public. For example, is to wear masks, do social distancing, and use hand sanitizer or disinfectant to cleanse hands and surfaces that often touched or operated in public. The demand of touchless equipment for public is increased, such as ticketing machine, payment,

Revised Manuscript Received on December 24, 2020

*Correspondence Author

Putri Amalia*, laboratory Assistant in Industrial Modelling and Simulation Laboratory, Faculty of Industrial Engineering, Universitas Islam Indonesia,

Setyawan Wahyu, Head of the Electronics Laboratory, Majoring in Electrical Engineering at the Islamic University of Indonesia

Diyas Aledya Yahya, Chemical Engineering, Faculty of Industrial Technology, Islamic University of Indonesia

Ari Adrianto, Studying Chemical Engineering at the Islamic University of Indonesia

(C) The Authors. Published by Blue Eyes Intelligence Engineering and Sciences Publication (BEIESP). This is an open access article under the CC BY-NC-ND license (http://creativecommons.org/licenses/by-nc-nd/4.0/) order to prevent the virus transmission, many regulations and other public facilities.

The new daily need of people which also increases during this pandemic and new normal era is hand sanitizer [4]. As a solution to cleanse the hand quickly and can be stored and used in public, hand sanitizer gets high demand. The main components of hand sanitizer are isopropyl alcohol, ethanol, and hydrogen [5]. After several months of pandemic, people now are curious to seek other antiseptics that can be used for daily life. A proposed product design will be built based on voice of customer about public facilities to prevent the spread of virus and will use House of Quality to deploy the proposed product. The output of this research is to propose the new product and to be implemented, specifically in Indonesia.

\section{LITERATURE REVIEW}

A research has been done by [6], found out that people redesigned interior design and facilities to prevent the spread of virus. This can be a chance for other researchers to develop new product to prevent the virus. One method that can be used to develop new product is Quality Function Deployment. QFD is critical for the initial stage of product development [7]. The research done by [8], the method used is QFD to redesign wheelchair based on the importance weights for the engineering characteristics. The input data is from Fuzzy-ANP approach and the result of the research is to propose the new dimension of wheelchair based on the ergonomics approach. House of Quality analysis also has been done by [9]. HOQ in that research utilized to support decision making in management and classify the proposed features of the product developed. Within this research, the author aimed to make a new product to support the new normal era with HOQ based on the preferences of expected user.

\section{RESEARCH METHOD}

In order to accomplish this research, the researchers used the research flow as seen in Fig 1. There are 4 main steps that will be conducted, from gain data, data processing, making HOQ matrix, and for the last is design the proposed product.

\section{A. Data Collection}

The primary data collection step in this research is done by online survey which aims to obtain primary data about the customers' desires towards the product, to become the voice of customers.

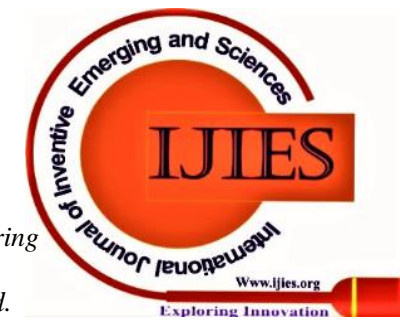




\section{Integrated Hand Cleaner and Dryer Product Design using QFD as a Solution for New Normal Era}

The secondary data used by the researchers ca

The input data of this research is customers preferences, that will be collected through questionnaire forms. The questionnaire is made and spread by online to reach many expected customers to fill the form. The data processing will be done in several steps, the first is to clean the unused data or uncomplete data. The reason of it is to make sure that the data used in the next process is the correct and has complete answers in the questionnaire. HOQ is used to deploy the needs of customer and how the researchers respond it. HOQ is a part of QFD or quality function deployment. The researchers will take 5 most popular answer to be the input of the HOQ matrix. There are 6 parts in the HOQ, which are the needs from customers, the technical measurements, planning matrix, relationship matrix, correlation matrix, and the last is benchmark. After the HOQ analysis is done, then the researchers will come up with design that are mostly needed and wanted by the expected customers. The design was built in $3 \mathrm{D}$ to make sure that it meets the voice of customers.

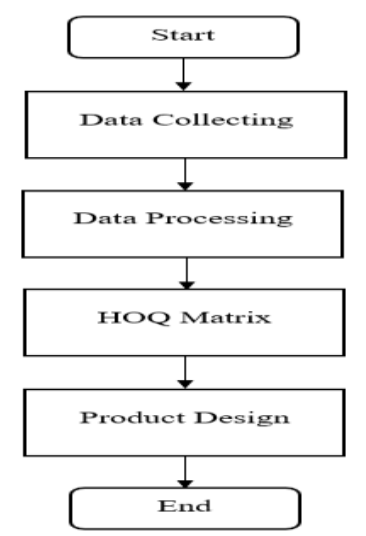

Fig. 1. Research Flow

\section{RESULT AND DISCUSSION}

There are 3 main parts in this section that will discuss in detail about the result from every stage in the research flow.

\section{A. Voice of Customers Identification}

The process of identify the voice of customers has been done using online survey or questionnaire that already gained 170 responses from both male and female, in the age range of 20-60 years old. From the result of the questionnaire, the researchers could identify the customers' requirements regarding the design of product, in this research is washbasin and its complements. There are many requirements as sampled in Table I. The researchers gained the most common requirements asked by the respondents, which are (1) should have dryer to prevent tissue shortage, (2) hygienic washbasin so it will not transfer viruses, (3) can be operated automatically, (4) ease of use. Those attributes then transformed into House of Quality matrix.

Table I. Voice of Customers

\begin{tabular}{|c|}
\hline User Request \\
\hline Provides a touchless hand wash \\
\hline Provide a dryer such as a hand dryer or tissue \\
\hline Provide hand washing soap. \\
\hline Provide a clean handwashing area \\
\hline
\end{tabular}

\section{B. House of Quality}

The following figure is the House of Quality which constructed based on the customers' requirements.

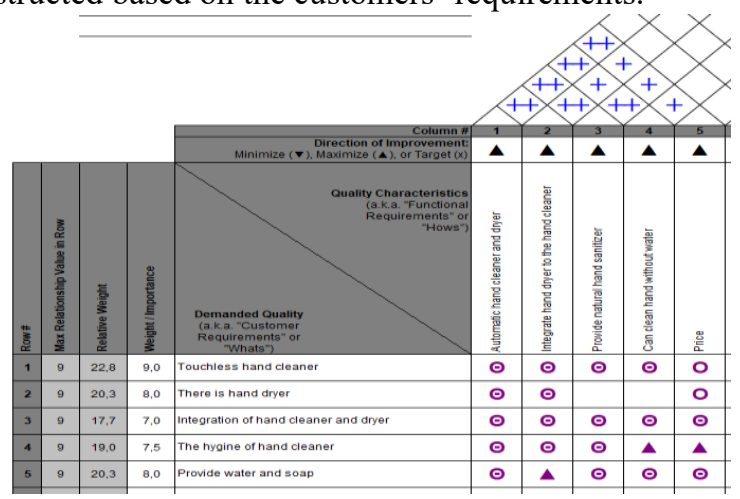

The result of customers' requirements then inputted to the HOQ matrix. The HOQ matrix aims to know the relationship between attributes of voice of customers and the technical responses. The importance rating then being assigned based on the online survey. The weight or importance rating then calculated in the House of Quality and become the consideration of the attributes determination towards the proposed product. There are five requirements from customers responsed by five technical requirements by the researchers to develop the product. The customers' requirements are: (1) touchless hand cleaner, (2) hygienic washbasin so it will not transfer viruses, (3) can be operated automatically, (4) all-in-one. In response to the customers' requirements, the technical requirements are: automatic hand cleaner and dryer, integration of hand cleaner and dryer, provide natural hand sanitizer, can clean hand without water, and price-economic.

\section{Product Design}

Based on the HOQ that has been discussed before, there are technical characteristics to develop the proposed product. From that, the researcher has developed HANDCY, an integrated hand cleaner and dryer that equipped with natural-based resource of hand sanitizer. It can replace washbasin since it can cleanse the user's hand but without water, operated automatically, and use sensor to make it touchless. HANDCY is very economic since the user will not pay the water bills and buy tissue, only need to refill the hand sanitizer if it is near to end.

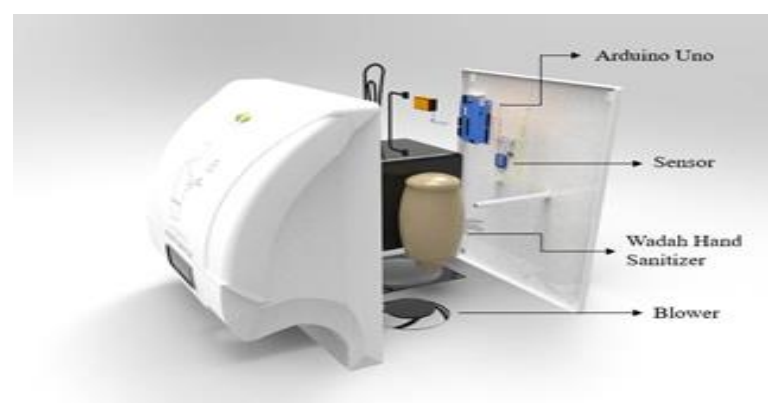

Fig. 1. HANDCY design using Exploded View and 3D Design.

Published By:

Blue Eyes Intelligence Engineering \& Sciences Publication

(C) Copyright: All rights reserved. 


\section{CONCLUSSION}

In this case of study has a purpose to get design of hand sanatory and dryer that suitable with the wishes of respondents (society). In this study, using QFD (quality function development) matrix of hoq (house of quality) based on customer preference. The procedural of hoq matrix includes seven steps. They are customer requirements (what), engineering requirements (how), development of a matrix of relationships between the customer requirements and engineering requirements, a matrix of relationships between the technical requirements, making a competitive assessment of the customer's competitive assessment and the competitive assessment of engineering, developing the customer requirements priority or respondents, developing technical priority requirements. The Data analysis indicates that the respondents tended to want the design of products that have hand sanitizers without touching, that the hygienic sink so as not to spread the virus, can be operated automatically, all in one. Based on the results of theresponders' needs, design of automatic hands cleaner and dryer. It is integrated in a tool that Use hand sanitizer with a natural antiseptic, so, it doesn't need water and very economist.

\section{REFERENCES}

1. G. O. Young, "Synthetic structure of industrial plastics (Book style with paper title and editor)," in Plastics, 2nd ed. vol. 3, J. Peters, Ed. New York: McGraw-Hill, 1964, pp. 15-64.

2. W.-K. Chen, Linear Networks and Systems (Book style). Belmont, CA: Wadsworth, 1993, pp. 123-135.

3. H. Poor, An Introduction to Signal Detection and Estimation. New York: Springer-Verlag, 1985, ch. 4.

4. B. Smith, "An approach to graphs of linear forms (Unpublished work style)," unpublished.

5. E. H. Miller, "A note on reflector arrays (Periodical style-Accepted for publication)," IEEE Trans. Antennas Propagat., to be published.

6. J. Wang, "Fundamentals of erbium-doped fiber amplifiers arrays (Periodical style-Submitted for publication)," IEEE J. Quantum Electron., submitted for publication.

7. C. J. Kaufman, Rocky Mountain Research Lab., Boulder, CO, private communication, May 1995.

8. Y. Yorozu, M. Hirano, K. Oka, and Y. Tagawa, "Electron spectroscopy studies on magneto-optical media and plastic substrate interfaces(Translation Journals style)," IEEE Transl. J. Magn.Jpn., vol. 2, Aug. 1987, pp. 740-741 [Dig. $9^{\text {th }}$ Annu. Conf. Magnetics Japan, 1982, p. 301].

9. M. Young, The Techincal Writers Handbook. Mill Valley, CA: University Science, 1989.

10. (Basic Book/Monograph Online Sources) J. K. Author. (year, month, day). Title (edition) [Type of medium]. Volume(issue).

Available: http://www.(URL)

11. J. Jones. (1991, May 10). Networks (2nd ed.) [Online]. Available: http://www.atm.com

12. (Journal Online Sources style) K. Author. (year, month). Title. Journal [Type of medium]. Volume(issue), paging if given.

Available: http://www.(URL)

\section{AUTHORS PROFILE}

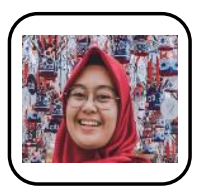

Putri Amalia, born in Magelang, Indonesia. As a graduate student of Industrial Engineering International Program, Putri Amalia already published several works in product design, supply chain management, and also in simulation modelling scope. Putri Amalia is currently a laboratory assistant in Industrial Modelling and Simulation Laboratory, Faculty of Industrial Engineering, Universitas Islam Indonesia, also take part in such research groups in Student Research Community. Has focused in operation research, Putri Amalia also has keen interest in design thinking to improve the work also to make new innovations in order to solve the current problems and make impact to the world.

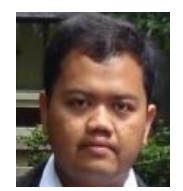

Setyawan Wahyu Pratomo, born in Surakarta, 26 September 1989. Received a Bachelor's degree Engineering (S.T.) in electrical engineering at the Telkom Institute of Technology / Telkom University and Masters of Engineering (M.T.) in electrical engineering at the University of Indonesia (UI).Now writer is a lecturer at the Islamic University Indonesia (UII), Yogyakarta in the field of electricity, especially wireless power transfer, is also active in coaching students in competitions in the field of technological innovation and implementing appropriate technology to society. Setyawan Wahyu Pratomo is currently the head of the electronics laboratory, majoring in electrical engineering at the Islamic University of Indonesia.

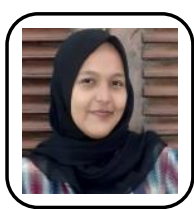

Diyas Aledya Yahya, was born in Cilacap, January 10, 2000. Diyas is a student of the Chemical Engineering study program of the Faculty of Industrial Technology, Islamic University of Indonesia class of 2017. During his studies,Diyas was actively involved in the organization and committee. The organization that has been followed is Students Research Community Faculty of Industrial Technology and Student Executive Institute of the Faculty of Industrial Technology, while the committee that was followed by one of them is the national deliberation BKKMTKI. In addition,Diyas is also an assistant to the Computational Laboratory of Process Chemical Engineering study program.

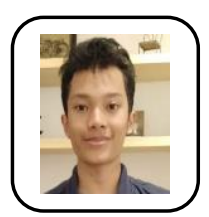

Ari Adrianto, was born in Jayapura, January 31, 2000 Currently studying chemical engineering at the Islamic University of Indonesia. Based on the experience that Ari Adrianto has. In 2017, he participated in a visit to a remote village in Bantul, Yogyakarta to provide education about the green environment and herbal medicine gardens. In 2018, he participated in the "LabmaMembangunDesa" activity where this activity was initiated to provide education to the community so that they could utilize the potential of their plantation to the community. And currently, he takes part of the 5 PM Nusantara project where the project is engaged in agriculture and the environment targeting all of Indonesia. They put forward efforts to improve farmer welfare, increase farmer productivity, and education related to crop protection.Based on his skills, he masters 3 languages: Indonesian, English and German. He has skills in the fields of graphic design, public relations, research and critical thinking.
Published By: Blue Eyes Intelligence Engineering \& Sciences Publication (C) Copyright: All rights reserved. 